\title{
Abundances of triclosan-degrading microorganisms in activated sludge systems
}

\author{
Do Gyun Lee ${ }^{1^{\dagger}}$, Kung-Hui $\mathrm{Chu}^{2}$ \\ ${ }^{1}$ Bren School of Environmental Science \& Management and Earth Research Institute, University of California, Santa Barbara, CA 93106, USA \\ ${ }^{2}$ Department of Civil Engineering, Texas A\&M University, TX 77843, USA
}

\begin{abstract}
Triclosan is a synthetic antimicrobial agent used in numerous industrial and personal care products. Triclosan collected in wastewater treatment plants can be biodegraded up to $80 \%$. However, little is studied about the abundances of known triclosan-degrading bacteria in activated sludge systems. A previous study reported that Sphingopyxis strain KCY1 isolated from activate sludge can cometabolically degrade triclosan. Recently, a quantitative PCR (qPCR) assay specific to strain KCY1 has been developed. Thus, this study investigated the abundance of strain KCY1 in three different activated sludge wastewater treatments using a qPCR assay. Additionally, ammonia-oxidizing bacteria (AOB), known as triclosan-degraders, and amo $A$ gene were quantified. Strain $\mathrm{KCY} 1$ were detected in activated sludge samples from three different wastewater treatment plants. The concentrations of strain KCY1 and AOB were on the order of $10^{5}-10^{6}$ gene copies $/ \mathrm{mL}$, while amoA gene concentration was on the order of $10^{4}$ gene copies $/ \mathrm{mL}$.
\end{abstract}

Keywords: Activated sludge, Ammonia-oxidizing Bacteria triclosan, Quantitative PCR, Triclosan-degrading bacteria

\section{Introduction}

Triclosan, a broad-spectrum antimicrobial agent, has been used in numerous industrial and personal care products [1, 2]. Triclosan is relatively non-volatile and inadequately soluble in water (solubility: $10 \mathrm{mg} / \mathrm{L}$ at $20^{\circ} \mathrm{C}$ ). Detection of triclosan in the aquatic environment has raised eco- and human health concern, due to the promotion of antibiotic-resistant microorganisms, its androgenicity as an endocrine disruptor, and the formation of potential toxic by-products [3-7]. Triclosan can be removed in a wastewater treatment plant (WWTP) with removal rates of $96 \%, 71 \%$, and $32 \%$, for activated sludge plant, for trickling filter plants and for primary treatment plants, respectively [8]. While a large portion of triclosan could be removed by biological treatment process in WWTPs, the remaining triclosan is continuously discharged into receiving water bodies; triclosan is removed via $79 \%$ biodegradation, $15 \%$ absorption to biosolids in WWTPs, and then $6 \%$ of triclosan release into the receiving surface water [9]. The rivers and creeks receiving a large quantity of triclosan-laden effluent may cause potential adverse effects to eco- and human health. Therefore, understanding of triclosan biodegradation by microorganisms during wastewater treatment processes is important to reduce triclosan release in to the environment.

Several studies have reported triclosan biodegradation by micro- organisms [10-15]. In activated sludge systems, ammonia-oxidizing bacteria (AOB) [13] and Sphingopyxis strain KCY1 [10] could play role in degrading triclosan. AOB can express ammonia monooxygenase (AMO) to oxidize ammonia to nitrite, which is the first step of nitrification process in nitrifying activated sludge (NAS). Roh et al. [13] suggested that AMO is responsible for triclosan degradation. Strain KCY1, isolated from activated sludge, has cometabolic degradative ability toward triclosan. Lee et al. [10] suggested that dioxygenase in strain KCY1 was involved in triclosan degradation.

Recently, a quantitative PCR (qPCR) assay specific to strain KCY1 was developed (unpublished work). Thus, this study investigated the abundance of strain KCY1 in different activated sludge systems usig a qPCR. In addition, the abundance of AOB and amo $A$ gene (encodes the active site of AMO for ammonia oxidation in $\mathrm{AOB}$ ) were quantified in activated sludge samples. The obtained results could provide insights into the abundances of triclosan-degrading bacteria in activated sludge systems.

\section{Materials and Methods}

\subsection{Activated Sludge Samples}

Activated sludge samples were collected in May 2009 from three
This is an Open Access article distributed under the terms of the Creative Commons Attribution Non-Commercial License (http://creativecommons. org/ licenses/by-nc/3.0/) which permits unrestricted non-commercial use, distribution, and reproduction in any medium, provided the original work is properly cited.
Received October 30, 2014 Accepted February 5, 2015

$\uparrow$ Corresponding author

Email: dlee@bren.ucsb.edu

Tel: +1-510-292-0393 Fax: +1-979-862-1542

Copyright (C) 2015 Korean Society of Environmental Engineers 
different WWTPs in College Station (WWTP \#1), Austin (WWTP \#2), and Houston (WWTP \#3) in Texas (Table 1). Additionally, NAS samples were collected in Nov. 2011 and May 2012 from WWTP \#1. These three WWTPs use different process configurations and operating conditions for BOD removal and nitrification (Table 1). WWTP \#1 and WWTP \#2 use single-stage activated sludge system. The WWTP\#1 treats 9.5 million gallons per day (MGD) and is operated at a solid retention time (SRT) of 7-8 days to achieve $97-98 \%$ BOD removal and $95 \%$ ammonia removal. The WWTP\#2 processes 75 MGD at a SRT of 10-12 days to achieve 97-99\% BOD removal and 99\% ammonia removal. The WWTP
\#3 uses two-stage activated sludge system to treat 200 MGD. By operating at a SRT of 2-20 days, the WWTP\#3 can remove 91-99\% of BOD and $84-99 \%$ of ammonia.

\subsection{DNA Extraction}

The genomic DNAs of activated sludge samples from the WWTPs were extracted using the FastDNA kits (MP Biomedicals, USA) as described previously [16], and then used as a template to quantify total microbial population, strain KCY1, AOB, and amoA gene. The extracted DNA concentrations were measured using a Hoefer DQ 300 Fluorometer (Hoefer Inc., USA).

Table 1. Operating Parameters of WWTPs where Activated Sludge Samples were Collected

\begin{tabular}{|c|c|c|c|c|}
\hline \multirow{2}{*}{ WWTPs operating parameters } & \multirow{2}{*}{ WWTP \#1 } & \multirow{2}{*}{ WWTP \#2 } & \multicolumn{2}{|c|}{ WWTP \#3 } \\
\hline & & & $1^{\text {st }}$ Stage & $2^{\text {nd }}$ Stage \\
\hline Treatment capacity (MGD*) & 9.5 & 75 & \multicolumn{2}{|c|}{200} \\
\hline SRT (day) & $7-8$ & $10-12$ & 2 & 20 \\
\hline MLVSS (g/L) & 2.15 & 1.52 & 1.35 & 1.10 \\
\hline $\mathrm{BOD}_{5}$ removal (\%) & 95 & $97-99$ & \multicolumn{2}{|c|}{$91-99$} \\
\hline $\begin{array}{l}\text { Ammonia removal (\%) } \\
\text { (influent concentration) }\end{array}$ & $\begin{array}{c}97-98 \\
(19-22 \mathrm{mg} / \mathrm{L})\end{array}$ & $\begin{array}{c}99 \\
(24-30 \mathrm{mg} / \mathrm{L})\end{array}$ & \multicolumn{2}{|c|}{$\begin{array}{c}\text { 84-99 } \\
(16-20 \mathrm{mg} / \mathrm{L})\end{array}$} \\
\hline
\end{tabular}

MGD*: Million gallon per day.

Table 2. Primers, Probes, and PCR Protocols of Quantitative PCR Assays used in this Study

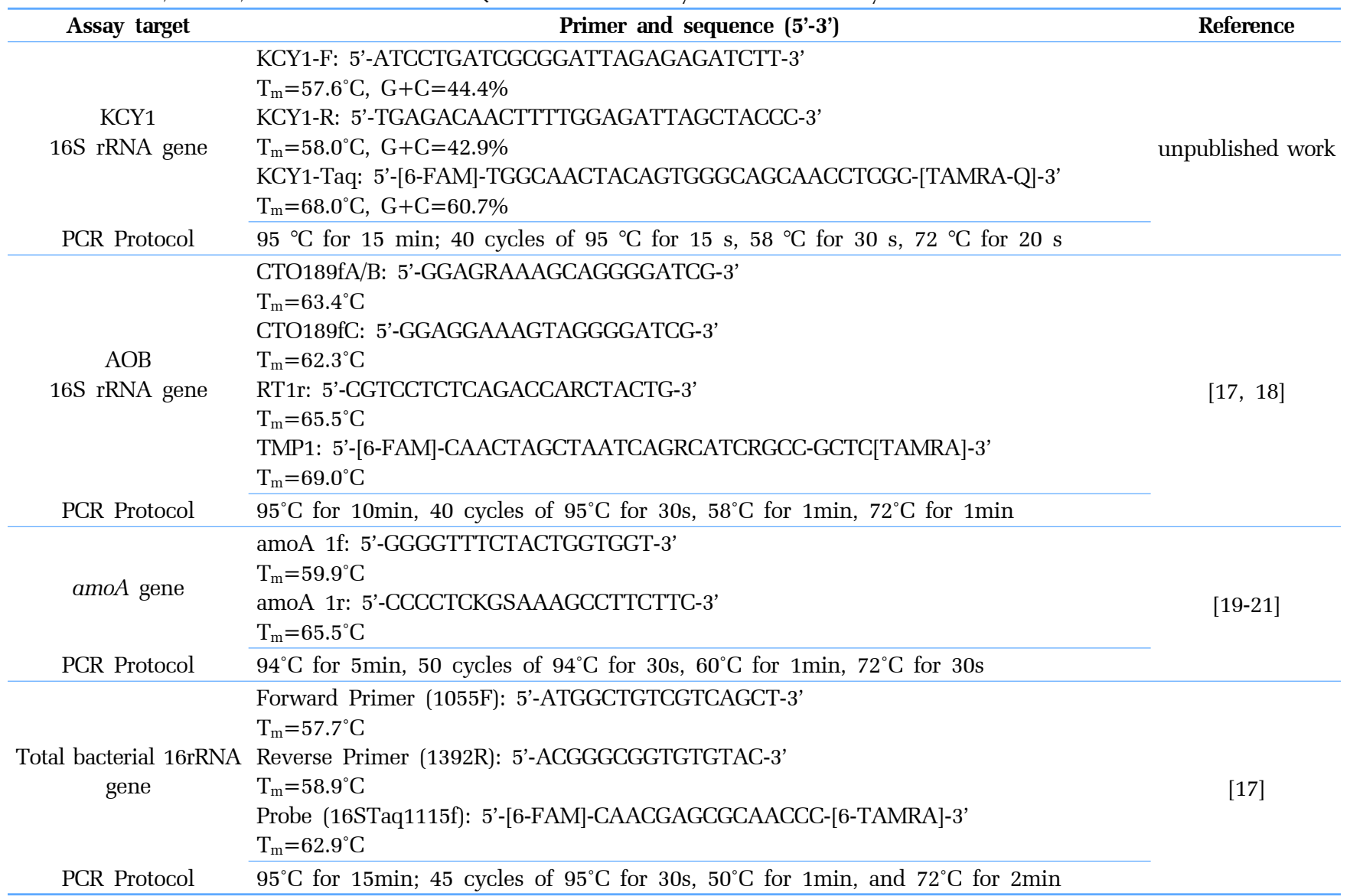

$\mathrm{T}_{\mathrm{m}}$ : melting temperature, $\mathrm{G}+\mathrm{C}: \mathrm{G}$ and $\mathrm{C}$ content.

$[6-\mathrm{FAM}]=6$-carboxyfluorescein, $[$ TAMRA $]=6$-carboxytetramethylrhodamine. 


\subsection{Quantitative PCR Assays}

The abundances of total bacteria, strain KCY1, AOB, and amoA gene in activated sludge samples were determined using qPCR with the genomic DNAs obtained from the activated sludge samples as templates. The primers (1055f and 1392r) and a probe (16S Taq1115f) were used for the quantification of total bacterial $16 \mathrm{~S}$ rRNA gene [17]. A set of forward and reverse primers (KCY1F/KCY1-R) and a Taqman probe (KCY1-Taq) for the 16S rRNA gene of strain KCY1 was used (unpublished work). The primers (CTO189fA/B and CTO189Fc) and a probe (TMP1) were used for the quantification of AOB $[17,18]$. The Primers (amoA if and amoA 1r) and SYBR Green I were used for the quantification of $a m o A$ genes [19-21]. The PCR mixture (25 $\mu \mathrm{L}$ of total volume) contained $600 \mathrm{nM}$ forward and reverse primers, $500 \mathrm{nM}$ of probe, $12.5 \mu \mathrm{L}$ of Taq Mastermix (or SYBR Green I for amoA gene), and 2-50 ng of DNA template. The PCR amplification reactions were performed using a Bio-Rad iQ5 Multicolor Quantitative PCR Detection System (Bio-Rad Laboratories Inc., USA). A standard curve for total bacterial $16 \mathrm{~S}$ rRNA gene (ranging from $2.3 \times 10^{1}$ to $2.3 \times 10^{8}$ gene copies) were constructed using plasmid \#931 with Nitrospira partial 16S rRNA gene (GenBank accession number AF420301) [16]. A standard curve for the AOB 16S rRNA gene (ranging from $1.0 \times 10^{1}$ to $1.0 \times 10^{9}$ gene copies) were constructed by using plasmid \#931 with Nitrosomonas europaea 16S rRNA (GenBank accession number AB070938). A standard curve for the strain KCY1 gene (ranging from $1.0 \times 10^{1}$ to $1.0 \times 10^{7} 16 \mathrm{~S}$ rRNA gene copies) was constructed using a plasmid \# 931 containing the partial 16S rRNA gene of strain KCY1. The details of primers, probes, and PCR amplification protocol were described in Table 2. Primers and probes for quantitative-PCR assays were purchased from Sigma-Aldrich (USA). Quanti-Tect probe PCR supermix and SYBR Green I were purchased from Qiagen (USA).

\section{Results and Discussion}

The quantities of total bacteria, strain KCY1, AOB and amoA gene in activated sludge samples collected from three WWTPs were determined using qPCR assays. The summary of the abundances are shown in Table 3. While the abundance of total bacteria was on the order of $10^{9} 16 \mathrm{~S}$ rRNA gene copies $/ \mathrm{mL}$, the sample in
November 2011 had the highest number of total bacteria $(8.2 \times$ $10^{9}$ gene copies $/ \mathrm{mL}$ ). Strain KCY1 was detected in all the activated sludge samples on the order of $10^{5}$ to $10^{7} 16 \mathrm{~S}$ rRNA gene copies $/ \mathrm{mL}$. The proportion of the quantified strain KCY1 16S rRNA genes with respect to total bacterial 16S rRNA genes varied from $0.03 \%$ to $0.7 \%$. One or two orders of magnitude differences in the quantity of strain KCY1 were observed in the WWTP \#1 activated sludge samples, i.e., lower in November $2011\left(2.2 \times 10^{5}\right.$ gene copies/mL) and higher, in May $2009\left(1.2 \times 10^{7}\right.$ gene copies/mL) and May 2012 $\left(1.4 \times 10^{6}\right.$ gene copies $\left./ \mathrm{mL}\right)$. Various factors, such as dissolved oxygen, solid retention time (SRT), nutrients, temperature and the presence of inhibitory compounds in activated sludge could affect the abundance of strain KCY1 in activated sludge. Thus, further study was regarding variations in strain KCY1 abundance is required.

In addition, the quantification in this study was performed based on single time points. Since occurrence and concentrations of triclosan-degrading bacteria measured in this study may vary depending on the time of sampling, additional research with expanded sampling is required to further investigate the trends of the abundances of triclosan-degrading bacteria in activated sludge system.

AOB were quantified on the order of $10^{5}$ to $10^{6}$ gene copies $/ \mathrm{mL}$ in the activated sludge samples. The proportion of the quantified AOB 16S rRNA gene with respect to total bacterial 16S rRNA gene varied from $0.007 \%$ to $0.08 \%$, which is similar to the range of the proportion (0.01-0.028\%) in domestic wastewater treatment plants [22]. Populations of strain KCY1 and AOB in the three activated sludge samples were comparable (on the order of $10^{5}-10^{6}$ gene copies $/ \mathrm{mL}$ ), despite that those were collected from the WWTPs with different configurations and operating conditions. The primers used in this study targets aerobic AOB affiliated with $\beta$ - subdivision of the class Proteobacteria [18]. Since, as of now, all the aerobic AOB isolated from non-marine ecosystems are member of $\beta$ - subdivision of the class Proteobacteria [23], this primer set could estimate well the abundance of $\mathrm{AOB}$ in the bacterial mixed culture such as activated sludge. However, as WWTPs operate with different ammonium concentrations in influent and SRT, different microbial community of AOB in activated sludge could be also established in activated sludge. As AOB are known as slow-growing microorganisms [24], their growth in activated sludge is favored at relatively longer SRT. Using pyrosequencing, identification of dominant groups of AOB established by different operating conditions

Table 3. Abundances of Sphingopyxis Strain KCY1, AOB, and amoA Gene in the WWTPs

\begin{tabular}{|c|c|c|c|c|c|c|}
\hline & \multirow{2}{*}{\multicolumn{3}{|c|}{ WWTP \#1 }} & \multirow{3}{*}{$\begin{array}{l}\text { WWTP \#2 } \\
\text { May } 2009\end{array}$} & \multicolumn{2}{|c|}{ WWTP \#3 } \\
\hline & & & & & $1^{\text {st }}$ Stage & $2^{\text {nd }}$ Stage \\
\hline & May 2009 & November 2011 & May 2012 & & \multicolumn{2}{|c|}{ May 2009} \\
\hline $\begin{array}{l}\text { Total bacteria } \\
\text { (\# copies/mL) }\end{array}$ & $1.7 \pm 1.3 \times 10^{9}$ & $8.2 \pm 2.5 \times 10^{9}$ & $4.9 \pm 1.4 \times 10^{9}$ & $2.1 \pm 3.2 \times 10^{9}$ & $3.0 \pm 0.7 \times 10^{9}$ & $1.4 \pm 2.9 \times 10^{9}$ \\
\hline $\begin{array}{c}\text { Strain KCY1 } \\
\text { ( \# copies } / \mathrm{mL})\end{array}$ & $1.2 \pm 1.5 \times 10^{7}$ & $2.2 \pm 3.1 \times 10^{5}$ & $1.4 \pm 4.3 \times 10^{6}$ & $2.4 \pm 7.3 \times 10^{6}$ & $4.5 \pm 2.5 \times 10^{6}$ & $6.4 \pm 7.1 \times 10^{5}$ \\
\hline $\begin{array}{c}\mathrm{AOB} \\
(\# \text { copies } / \mathrm{mL})\end{array}$ & ${ }^{*} 1.5 \times 10^{5}$ & $5.4 \pm 6.7 \times 10^{5}$ & $4.2 \pm 2.6 \times 10^{5}$ & ${ }^{*} 1.6 \times 10^{6}$ & ${ }^{*} 1.9 \times 10^{5}$ & ${ }^{\ddagger} 7.4 \times 10^{5}$ \\
\hline $\begin{array}{c}\text { amo } A \text { gene } \\
(\# \text { copies } / \mathrm{mL})\end{array}$ & ${ }^{\neq} 1.7 \times 10^{4}$ & $3.6 \pm 3.5 \times 10^{4}$ & $7.1 \pm 6.9 \times 10^{4}$ & ${ }^{\neq} 4.6 \times 10^{4}$ & ${ }^{\neq} 2.1 \times 10^{4}$ & ${ }^{\ddagger} 1.5 \times 10^{4}$ \\
\hline
\end{tabular}

${ }^{\mp}$ Data about $\mathrm{AOB}$ and $a m o A$ were cited from Roh et al. [28]. 
would be interesting for future study. It is also needed to be aware of the overestimation of AOB 16S rRNA gene copies, because multiple of identical 16S rRNA sequences can be found among bacterial genomes (i.e., the number of AOB 16S rRNA gene copies does not indicate the number of AOB).

The number of $a m o A$ gene copies (ranging between $1.5-2.1 \times 10^{4}$ gene copies $/ \mathrm{mL}$ ) in activated sludge samples was one to two orders of magnitude lower than the number of AOB $16 \mathrm{~S}$ rRNA gene copies. The proportion of the quantified $a m o A$ gene with respect to total bacterial $16 \mathrm{~S}$ rRNA gene ranged from $0.0004 \%$ to $0.001 \%$, which is lower than the range of the proportion $(0.0023-0.20 \%)$ in domestic wastewater treatment plants [22]. No correlation between AOB 16S rRNA gene copy numbers and amoA gene copy numbers was observed. Like AOB, ammonia-oxidizing archaea (AOA) have amoA-like genes and could also contribute to the detection of amoA gene in activated sludge. Although AOA can be present in activated sludge collected for this study [25, 26], several studies have reported the variation of the presence and concentrations of AOA may vary depending on ammonium concentrations in wastewater [25-27]. Investigation of the presence and concentrations of AOA would be required for future study.

\section{Conclusions}

This study examines the abundances of strain KCY1 and AOB that are capable of triclosan degradation in three different activated sludge using qPCR assays. Strain KCY1 and AOB were detected on the order of $10^{5}-10^{6}$ gene copies $/ \mathrm{mL}$. The number of amoA gene was also observed on the order of $10^{4}$ gene copies $/ \mathrm{mL}$. The information about the abundances of triclosan-degrading microorganisms would be useful to better understand triclosan degradation by biological treatment process in activated sludge systems. Based on the results of the abundances of triclosan-degrading bacteria, establishing the conditions favorable for $\mathrm{AOB}$ and strain KCY1 activity or bioaugmenting with known triclosan-degrading microorganisms or newly isolated bacteria from activated sludge could also be possible strategies to enhance triclosan degradation in WWTPs.

\section{References}

1. Sabaliunas D, Webb SF, Hauk A, Jacob M, Eckhoff WS. Environmental fate of triclosan in the River Aire Basin, UK. Water Res. 2003;37:3145-3154.

2. Schweizer HP. Triclosan: a widely used biocide and its link to antibiotics. FEMS Microbiol. Lett. 2001;202:1-7.

3. Latch DE, Packer JL, Arnold WA, McNeill K. Photochemical conversion of triclosan to 2,8-dichlorodibenzo-p-dioxin in aqueous solution. J. Photochem. Photobiol. A Chem. 2003;158: 63-66.

4. Hundt K, Martin D, Hammer E, Jonas U, Kindermann MK, Schauer F. Transformation of triclosan by Trametes versicolor and Pycnoporus cinnabarinus. Appl. Environ. Microbiol. 2000;66:4157-4160.
5. Foran CM, Bennett ER, Benson WH. Developmental evaluation of a potential non-steroidal estrogen: triclosan. Mar. Environ. Res. 2000;50:153-156.

6. Braoudaki M, Hilton AC. Low level of cross-resistance between triclosan and antibiotics in Escherichia coli K-12 and E. coli O55 compared to E.coli O157. FEMS Microbiol. Lett. 2004;235: 305-309.

7. Chen X, Casas ME, Nielsen JL, Wimmer R, Bester K. Identification of triclosan-o-sulfate and other transformation products of triclosan formed by activated sludge. Sci. Total Environ. 2015;505:39-46.

8. McAvoy DC, Schatowitz B, Jacob M, Hauk A, Eckhoff WS. Measurement of triclosan in wastewater treatment systems. Environ. Toxicol. Chem. 2002;21:1323-1329.

9. Singer H, Mueller S, Tixier C, Pillonel L. Triclosan: occurrence and fate of a widely used biocide in the aquatic environment: field measurements in wastewater treatment plants, surface waters, and lake sediments. Environ. Sci. Technol. 2002;36: 4998-5004.

10. Lee DG, Zhao F, Rezenom YH, Russell DH, Chu KH. Biodegradation of triclosan by a wastewater microorganism. Water Res. 2012;46:4226-4234.

11. Lee DG, Cho KC, Chu KH. Identification of triclosan-degrading bacteria in a triclosan enrichment culture using stable isotope probing. Biodegradation 2014;25:55-65.

12. Lee DG, Chu KH. Effects of growth substrate on triclosan biodegradation potential of oxygenase-expressing bacteria. Chemosphere 2013;93:1904-1911.

13. Roh H, Subramanya N, Zhao F, Yu CP, Sandt J, Chu KH. Biodegradation potential of wastewater micropollutants by ammonia-oxidizing bacteria. Chemosphere 2009;77:1084-1089.

14. Hay AG, Dees PM, Sayler GS. Growth of a bacterial consortium on triclosan. FEMS Microbiol. Lett. 2001;36:105-112.

15. Taştan BE, Dönmez G. Biodegradation of pesticide triclosan by A. versicolor in simulated wastewater and semi-synthetic media. Pestic. Biochem. Physiol. 2015;118:33-37.

16. Yu CP, Ahuja R, Sayler G, Chu KH. Quantitative molecular assay for fingerprinting microbial communities of wastewater and estrogen-degrading consortia. Appl. Environ. Microbiol. 2005;71:1433-1444.

17. Harms G, Layton AC, Dionisi HM, et al. Real-time PCR quantification of nitrifying bacteria in a municipal wastewater treatment plant. Environ. Sci. Technol. 2003;37:343-351.

18. Hermansson A, Lindgren PE. Quantification of ammonia-oxidizing bacteria in arable soil by real-time PCR. Appl. Environ. Microbiol. 2001;67:972-976.

19. Rotthauwe JH, Witzel KP, Liesack W. The ammonia monooxygenase structural gene $a m o A$ as a functional marker: Molecular fine-scale analysis of natural ammonia-oxidizing populations. Appl. Environ. Microbiol. 1997;63:4704-4712.

20. Hoshino T, Terahara T, Tsuneda S, Hirata A, Inamori Y. Molecular analysis of microbial population transition associated with the start of denitrification in a wastewater treatment process. J. Appl. Microbiol. 2005;99:1165-1175.

21. Araki N, Yamaguchi T, Yamazaki S, Harada H. Quantification of $a m o A$ gene abundance and their amoA mRNA levels in 
activated sludge by real-time PCR. Water Sci. Technol. 2004; 50:1-8.

22. Geets J, De Cooman M, Wittebolle L, et al. Real-time PCR assay for the simultaneous quantification of nitrifying and denitrifying bacteria in activated sludge. Appl. Microbiol. Biotechnol. 2007;75:211-221.

23. Kowalchuk GA, Stephen JR. Ammonia-oxidizing bacteria: a model for molecular microbial ecology. Annu. Rev. Microbiol. 2001;55:485-529.

24. Painter H, Loveless J. Effect of temperature and $\mathrm{pH}$ value on the growth-rate constants of nitrifying bacteria in the activated-sludge process. Water Res. 1983;17:237-248.

25. Zhang T, Jin T, Yan Q, et al. Occurrence of ammonia-oxidizing archaea in activated sludges of a laboratory scale reactor and two wastewater treatment plants. J. Appl. Microbiol. 2009;107: 970-977.

26. Park HD, Wells GF, Bae H, Criddle CS, Francis CA. Occurrence of ammonia-oxidizing archaea in wastewater treatment plant bioreactors. Appl. Environ. Microbiol. 2006;72:5643-5647.

27. Limpiyakorn T, Sonthiphand P, Rongsayamanont C, Polprasert C. Abundance of $a m o A$ genes of ammonia-oxidizing archaea and bacteria in activated sludge of full-scale wastewater treatment plants. Bioresour. Technol. 2011;102:3694-3701.

28. Roh H, Chu KH. A 17ß-estradiol-utilizing bacterium, Sphingomonas strain KC8: part I - characterization and abundance in wastewater treatment plants. Environ. Sci. Technol. 2010;44:4943-4950. 